\title{
Comparison of Satisfaction Level of Customers between Public and Private Commercial Banks in Kathmandu Valley
}

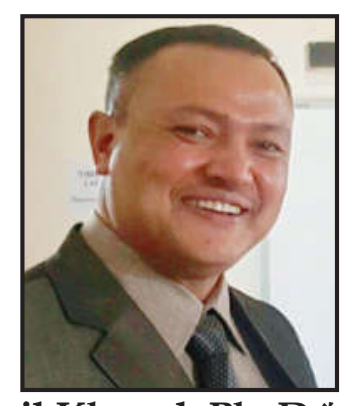

Kapil Khanal, Ph. D.*

\begin{abstract}
The intention of the study was to identify the various important service quality dimensions in commercial banking industry in Kathmandu valley. Data was collected through questionnaire and this questionnaire was distributed among 240 customers of 28 commercial banks. Random sampling technique was used in this procedure. Arithmetic means, standard deviation and factor analysis were used to analyze and interpret data. It has been found that customer of public sector bank perceived highest value in assurance dimension, like safety in transaction and consistency in services. The Research has revealed that the highest Eigen value (7.486) in Reliability dimension. There exists a positive relation overall and boost job satisfaction, which would in turn enhance the productivity of the organization.
\end{abstract}

Article type: Research Paper

Key words: Customer Satisfaction, Service Quality, Customer Centrism, Customer Relationship Management

\section{Introduction}

The banking industry in Nepal has undergone great change after democracy in the country. More recently, liberalization, the opening up of the economy in the 1990s and the government's decision to privatize banks by reduction in state ownership culminated in the banking reforms based on the recommendations of the various committees. This has led the Nepalese banking industry to experience difficult times. In such testing times of mature and acute competitive pressures, it is very urgent and important that banks are able to retain a loyal base of clients. To attain this and to improve their market and profit positions, banks in India have to formulate their strategies and policies towards increasing customer satisfaction levels.

Banking institutions across the globe have recognized the importance of customer satisfaction and of developing and maintaining enduring relationship with their customers as two crucial parameters leading to increased business profits. At the same time, several banking institutions are experiencing increasing level of retail customer dissatisfaction. Research suggests that customer dissatisfaction is still the major reason of bank customers' switch to other banks (Manrai and Manrai, 2007). This dissatisfaction could be because of a variety of reasons.

* Associate Professor, Shanker Dev Campus, Tribhuvan University, Nepal 
Excellent service quality is not an optional competitive strategy which may, or may not, be adopted to differentiate one bank from another: today it is essential to corporate profitability and survival. The link between service quality and customer satisfaction has been submitted to intense scrutiny by leading service quality researchers (Bitner and Hubbert,1994; Bolton and Drew,1994), as well as the links between quality, customer satisfaction, customer retention and profitability (Storbacka et al., 1994). The connection between service quality and corporate profitability is now seen to depend on high levels of customer satisfaction, the successful targeting of "quality" customers and the retention of those customers.

\section{Literature Review}

Customer satisfaction has been considered the essence of success in today's highly competitive banking industry. Prabhakaran and Satya (2003) mentioned that the customer is the king. Heskett et al. (1997) argued that profit and growth are stimulated primarily by customer loyalty. Ndubisi (2005), Gee et al. (2008) and Pfeifer (2005) pointed out that the cost of serving a loyal customer is five or six times less than a new customer. Several researchers including Tariq and Moussaoui (2009), Han et al. (2008) and Ehigie (2006) found that loyalty is a direct outcome of customer satisfaction. Generally speaking, if the customers are satisfied with the provided goods or services, the probability that they use the services again increases (East, 1997). Also, satisfied customers will most probably talk enthusiastically about their buying or the use of a particular service; this will lead to positive advertising (File and Prince, 1992; Richens, 1983). On the other hand, dissatisfied customers will most probably switch

to a different brand; this will lead to negative advertising (Nasserzadeh et al., 2008). The significance of satisfying and keeping a customer in establishing strategies for a market and customer oriented organization cannot be ignored (Kohli and Jaworski, 1990).

Most of the researchers found that service quality is the antecedent of customer satisfaction (Bedi, 2010; Kassim and Abdullah, 2010; Kumar et al., 2010; Yee et al., 2010; Kumar et al., 2009; Naeem and Saif, 2009; Balaji, 2009; Parasuraman et al., 1988). Quality customer service and satisfaction are recognized as the most important factors for bank customer acquisition and retention (Jamal, 2004; Armstrong and Seng, 2000; Lassar et al., 2000). Service quality is considered as one of the critical success factors that influence the competitiveness of an organization. A bank can differentiate itself from competitors by providing high quality service. Service quality is one of the most attractive areas for researchers over the last decade in the retail banking sector (Avkiran, 1994; Stafford, 1996; Johnston and Jeffrey, 1996; Angur et al., 1999; Lassar et al., 2000; Bahia and Nantel, 2000; Sureshchandar et al., 2002; Gounaris et al., 2003; Choudhury, 2008).

According to Tse and Wilton (1988) Customer satisfaction is, "the consumer's response to the evaluation of the perceived discrepancy between prior expectations and the actual performance of the product perceived after its consumption. The service quality variables identified by Parasuraman et al., (1994) are reliability, responsiveness, competence, accessibility, courtesy, communication, credibility, security, understanding and tangibility. Alfred and Addam (2001) investigated attitudes using fifteen service quality variables. In the present study, the 
service quality in retail banking is studied using variables drawn from the reviews (Cronin and Taylor 1992; Zillur Rahman, 2005; Verma and Vohna 2000; Mushtag A Bhat, 2005).

\section{Objectives of the Study}

For this study, following objectives have been formed:

1. To identify the various important service quality dimension in commercial banking industry in Kathmandu valley.

2. To compare the satisfaction level of customers between public and private commercial banks in each service dimension.

\section{Research Methodology}

Due to fierce competition amongst various banks in Nepalese context with liberalization and privatization, there is requirement to provide better value service to their customer, so customers become loyal. Now a day customer satisfaction and customer retention are the most important challenges faced by most of banking.

A systematic and coherent approach has been adopted for the research study. First, the objectives of the study were chalked out on the basis of focus group discussion and exhaustive literature review. Based on literature review, items were identified to assess the satisfaction level of Bank customers. Apart from the items from the SERVQUAL model (in a modified form), additional items of RATER dimensions sorted by relative importance (Zeithaml 1990) were taken. For identifying the satisfaction factors, the respondents were asked to rate their bank on various categories. All the items were put on a five-point likert scale ranging from strongly disagree to strongly agree.

For the data collection, sample of 240 customers who have their bank account with different banks having operations in Kathmandu Valley on convenience basis. Thereafter, the questionnaire was administered to customers for giving their response on banks service quality.

\section{Analysis and Findings}

The demographic details of respondents on the various parameters like Gender, Age group, Education, Occupation and Income group was described in Table:1 as follows: 
Table 1: Demographic Analysis

\begin{tabular}{|c|c|c|}
\hline Parameters & No. of Respondents & Percentage (\%) \\
\hline \multicolumn{3}{|l|}{ Gender } \\
\hline Male & 166 & 69.16 \\
\hline Female & 74 & 30.84 \\
\hline Total & 240 & 100 \\
\hline \multicolumn{3}{|l|}{ Age Group } \\
\hline Below 25 & 116 & 48.34 \\
\hline Between 25-35 & 38 & 15.83 \\
\hline Between34-45 & 32 & 13.33 \\
\hline Above 45 & 54 & 22.5 \\
\hline Total & 240 & 100 \\
\hline \multicolumn{3}{|l|}{ Occupation } \\
\hline Business & 52 & 21.67 \\
\hline Service & 38 & 15.83 \\
\hline Self-employed & 28 & 11.67 \\
\hline Others (Stu. HWs etc.) & 122 & 50.83 \\
\hline Total & 240 & 100 \\
\hline \multicolumn{3}{|l|}{ Qualification } \\
\hline Under Graduate & 62 & 25.83 \\
\hline Graduate & 98 & 40.84 \\
\hline Post Graduate & 78 & 32.5 \\
\hline Others & 2 & 0.83 \\
\hline Total & 240 & 100 \\
\hline \multicolumn{3}{|l|}{ Annual Income } \\
\hline Below 1,50,000 & 138 & 57.5 \\
\hline Between 1,50,000-3,00,000 & 52 & 21.67 \\
\hline Between 3,00,000-5,00,000 & 44 & 18.33 \\
\hline Above $5,00,000$ & 6 & 2.5 \\
\hline Total & 240 & 100 \\
\hline
\end{tabular}

Source: Primary Customer Survey, 2018

Based on the discussions with the clients in the pilot study and in-depth literature review, an exhaustive list of 16 items was identified as shown in Table II. The list is all-inclusive as these items were meticulously drawn out after through interviews and comprehensive literature review. Based on these 16 items, a questionnaire was prepared. For identifying the satisfaction factors, the respondents were asked to rate their bank on these 16 items. All the items were put on a five- point likert scale ranging from strongly disagree to strongly agree. The questionnaire was tested on 240 respondents and their responses were statistically tested in SPSS and mean was computed for their ratings. From the mean scores of service quality it has been found that customer of public sector bank perceived highest value in assurance dimension, like safety in transaction and consistency in services. While on other hand customer of private sector bank perceived highest value in tangible dimension and the in reliability dimension. 
Table: 2 Service Quality rating for Public sector and Private sector banks

\begin{tabular}{|c|c|c|c|}
\hline $\begin{array}{l}\text { Sr. } \\
\text { No. }\end{array}$ & Service quality & $\begin{array}{l}\text { Public Sector } \\
\text { Bank (Mean) }\end{array}$ & $\begin{array}{l}\text { Private Sector } \\
\text { bank (Mean) }\end{array}$ \\
\hline & Reliability & & \\
\hline 1 & $\begin{array}{l}\text { When my bank promises to do something by a } \\
\text { certain time, it does so. }\end{array}$ & 2.2833 & 4.0333 \\
\hline 2 & $\begin{array}{l}\text { When I have problem, my bank shows sincere } \\
\text { interest in solving it. }\end{array}$ & 2.65 & 4.0166 \\
\hline \multirow[t]{2}{*}{3} & My bank delivers error free records & 3.0666 & 3.6666 \\
\hline & Responsiveness & & \\
\hline 4 & Employee in my bank gives prompt service. & 1.8666 & 3.8666 \\
\hline 5 & $\begin{array}{l}\text { Employees in my banks are always willing to help } \\
\text { me. }\end{array}$ & 3.15 & 3.85 \\
\hline \multirow[t]{2}{*}{6} & $\begin{array}{l}\text { Employee in my bank will tell me exactly when } \\
\text { the service will be performed. }\end{array}$ & 2.35 & 3.9 \\
\hline & Assurance & & \\
\hline 7 & $\begin{array}{l}\text { The behavior of employees in my bank will instill } \\
\text { confidence to me. }\end{array}$ & 3.05 & 3.4166 \\
\hline 8 & I feel safe in my transaction with my bank. & 3.8833 & 3.35 \\
\hline 9 & $\begin{array}{l}\text { Employees in my bank are consistency courteous } \\
\text { with me. }\end{array}$ & 3.55 & 3.85 \\
\hline \multirow[t]{2}{*}{10} & $\begin{array}{l}\text { Employees in my bank have the knowledge to } \\
\text { answer my questions }\end{array}$ & 3.25 & 3.5166 \\
\hline & Empathy & & \\
\hline 11 & $\begin{array}{l}\text { The employee of my bank understands my specific } \\
\text { need. }\end{array}$ & 3.20 & 3.1833 \\
\hline 12 & $\begin{array}{l}\text { My bank has operating hours convenient to all its } \\
\text { customers. }\end{array}$ & 2.6333 & 3.75 \\
\hline \multirow[t]{2}{*}{13} & My bank gives me individual attention. & 3.0833 & 3.45 \\
\hline & Tangible & & \\
\hline 14 & My bank has modern looking equipment. & 2.7666 & 3.9833 \\
\hline 15 & My bank's employees are neat appearing. & 2.8166 & 4.1166 \\
\hline 16 & $\begin{array}{l}\text { My bank's physical facilities and amenities are } \\
\text { satisfactory. }\end{array}$ & 2.95 & 4.1333 \\
\hline
\end{tabular}

Source: Primary Customer Survey, 2018

To know further detail about relationship between factor and there correlation, Factor analysis was performed using SPSS software and we have found that KMO (Kaiser-Meyer-Olkin Measure of Sampling Adequacy) test, adequacy value must be more than 0.50 , in this case it was 0.649 ( See Table: III) . Second test is Bartlett's Test of Sphericity, here p value must be less than 0.001 . 
Table 3: KMO \& Bartlett's Test

Kaiser-Meyer-Olkin Measure of Sampling Adequacy. .649

\begin{tabular}{|l|l|l|}
\hline Bartlett's Test of Sphericity & Approx. Chi-Square & 1213.35 \\
\hline & $\mathrm{df}$ & 120 \\
\hline & Sig.(P) & .000 \\
\hline
\end{tabular}

Source: Primary Customer Survey, 2018

Since the satisfaction variables were large in number and were inter-related, factor analysis was done to extract the factors affecting the satisfaction of clients. PCA was the method of extraction. Varimax was the rotation method. As per the Kaiser (1960) criterion, only factors with eigen values greater than one were retained. Five factors in the initial solution have eigen values greater than one. Together, they accounted for almost 70 percent of the variability in the original variables, which can be regarded as well beyond sufficient. After extracting the eigen values, rotation of principal components was done through varimax rotation (see Table: IV). After the number of extracted factors was decided upon, the next step was to interpret the factors by identifying which factors were associated with the original variables.

Table 4: Factor Extraction by varimax rotation

\begin{tabular}{|l|l|l|l|l|l|l|}
\hline \multirow{2}{*}{ Component } & \multicolumn{3}{|l|}{ Initial Eigen values } & \multicolumn{3}{l|}{ Extraction Sums of Squared Loadings } \\
\cline { 2 - 7 } & Total & $\%$ of Variance & $\begin{array}{l}\text { Cumulative } \\
\%\end{array}$ & Total & $\%$ of Variance & $\begin{array}{l}\text { Cumulative } \\
\%\end{array}$ \\
\hline 1 & 3.517 & 34.482 & 34.482 & 5.517 & 34.482 & 34.482 \\
\hline 2 & 2.215 & 13.844 & 48.327 & 2.215 & 13.844 & 48.327 \\
\hline 3 & 1.754 & 10.964 & 59.291 & 1.754 & 10.964 & 59.291 \\
\hline 4 & 1.276 & 7.977 & 67.268 & 1.276 & 7.977 & 67.268 \\
\hline 5 & 1.227 & 7.666 & 74.934 & 1.227 & 7.666 & 74.934 \\
\hline 6 & .840 & 5.249 & 80.183 & & & \\
\hline 7 & .751 & 4.697 & 84.880 & & & \\
\hline 8 & .586 & 3.659 & 88.539 & & & \\
\hline 9 & .471 & 2.945 & 91.484 & & & \\
\hline 10 & .346 & 2.162 & 93.646 & & & \\
\hline 11 & .294 & 1.840 & 95.486 & & & \\
\hline 12 & .263 & 1.645 & 97.131 & & & \\
\hline 13 & .164 & 1.024 & 98.155 & & & \\
\hline 14 & .136 & .852 & 99.007 & & & \\
\hline 15 & .094 & .585 & 99.592 & & & \\
\hline 16 & .065 & .408 & 100.000 & & & \\
\hline
\end{tabular}

Source: Primary Customer Survey, 2018 
The factor analysis results in five important service quality factors namely reliability, responsiveness, assurance, empathy and tangibles. The factor loading of the service quality variables included in the above said five factors and its reliability co-efficient, the Eigen value and the per cent of variation explained by the service quality factors are presented in Table V.

The Researcher has found highest Eigen value (7.486) in Reliability dimension. It carries three service quality variables like; fulfill promise within certain time limit, error free records and show sincere interest in solving customer problem. Within that reliability dimension they give more focus on how banks fulfill their promise. It got highest Eigen value in all sixteen service quality variables.

Table 5: Factor association with other dependent factors

\begin{tabular}{|c|c|c|c|c|c|}
\hline Dimension & Que. & $\begin{array}{c}\text { Eigen } \\
\text { Values }\end{array}$ & $\begin{array}{l}\text { Factor } \\
\text { Loading }\end{array}$ & $\begin{array}{c}\text { Percentage } \\
\text { variance }\end{array}$ & $\begin{array}{c}\text { Commutative } \\
\text { Percentage }\end{array}$ \\
\hline \multirow{3}{*}{ Reliability } & Q1 & \multirow[b]{3}{*}{7.486} & .839 & 34.482 & 34.482 \\
\hline & Q2 & & .758 & 13.844 & 48.327 \\
\hline & Q3 & & .830 & 10.964 & 59.291 \\
\hline \multirow{3}{*}{ Responsiveness } & Q4 & \multirow[b]{3}{*}{3.343} & .596 & 7.977 & 67.268 \\
\hline & Q5 & & .870 & 7.666 & 74.934 \\
\hline & Q6 & & .793 & 5.249 & 80.183 \\
\hline \multirow{4}{*}{ Assurance } & Q7 & \multirow[b]{4}{*}{2.154} & .766 & 4.697 & 84.880 \\
\hline & Q8 & & .695 & 3.659 & 88.539 \\
\hline & Q9 & & .807 & 2.945 & 91.484 \\
\hline & Q10 & & .654 & 2.162 & 93.646 \\
\hline \multirow{3}{*}{ Empathy } & Q11 & \multirow[b]{3}{*}{0.721} & .869 & 1.840 & 95.486 \\
\hline & Q12 & & .700 & 1.645 & 97.131 \\
\hline & Q13 & & .732 & 1.024 & 98.155 \\
\hline \multirow{3}{*}{ Tangibility } & Q14 & \multirow[b]{3}{*}{0.295} & .722 & .852 & 99.007 \\
\hline & Q15 & & .672 & .585 & 99.592 \\
\hline & Q16 & & .686 & .408 & 100.000 \\
\hline
\end{tabular}

Source: Primary Customer Survey, 2018

Second important dimension was Responsiveness. It also consist three service quality variables with second highest Eigen value (3.343). It includes various criteria like, promptness in giving service, willingness to help customers etc. Within Responsiveness customer gives more importance to how bank gives prompt service to them. Next three service dimension are Assurance, Empathy and Tangibility with Eigen value of 2.154, 0.721 and 0.295 respectively. 


\section{Conclusion}

Service qualities of private and public banks were measured by using SERQUAL method. The result of this study provides evidence that the SERQUAL dimensions are useful tool to predict over all service performance of banks. In this paper we have found that a customer gives highest impotence to reliability dimension. Within that reliability dimension they give more focus on how banks fulfill their promise and how they show interest to do work. From Analysis it was found that a customer gives second importance to responsiveness of bank employees. It includes various criteria like, promptness in giving service, willingness to help customers etc. Customer gives third preference to assurance factor, it include criteria like safety of transaction, consistency in service etc.

So, banks whether they are private sector bank or public sector bank they should give more focus on increasing reliability, responsiveness and assurance. For that they can give training to their employee which will help them to give personalized service. It will also help to implement empathetic approach.

\section{References}

Angur, M.G., Nataraajan, R. and Jahera, J.S. (1999), "Service quality in the banking industry: an assessment in a developing economy", International Journal of Bank Marketing, Vol. 17 No. 3, pp. 116-23.

Armstrong, R.W. and Seng, T.B. (2000), "Corporate-customer satisfaction in the banking industry of Singapore", International Journal of Bank Marketing, Vol. 18 No. 3, pp. 97-111.

Bedi, M. (2010), “An integrated framework for service quality, customer satisfaction and behavioral responses in Indian banking industry: a comparison of public and private sector banks", Journal of Services Research, Vol. 10 No. 1, pp. 157-72.

Carman, J.M. (1990), "Consumer perceptions of service quality: an assessment of the SERVQUAL dimensions", Journal of Retailing, Vol. 66, pp. 33-5.

Choudhury, K. (2008), "Service quality: insights from the Indian banking scenario", Australasian Marketing Journal, Vol. 16 No. 1, pp. 48-61.

Cui, C.C., Lewis, B.R. and Park, W. (2003), "Service quality measurement in the banking sector in South Korea", International Journal of Bank Marketing, Vol. 21 No. 4, pp. 191-201.

Gee, R., Coates, G. and Nicholson, M. (2008), "Understanding and profitably managing customer loyalty", Marketing Intelligence \& Planning, Vol. 26 No. 4, pp. 359-74.

Gounaris, S.P., Stathakopoulos, V. and Athanassopoulos, A.D. (2003), "Antecedents to perceived service quality: an exploratory study in the banking industry", The International Journal of Bank Marketing, Vol. 21 Nos 4/5, pp. 168-90.

Jamal, A. and Naser, K. (2002), “Customer satisfaction and retail banking: an assessment of some of the key antecedents of customer satisfaction in retail banking", International Journal of Bank Marketing, Vol. 20 No. 4, pp. 146-60. 
Jamal, A. and Naser, K. (2003), "Factors influencing customer satisfaction in the retail banking sector in Pakistan", International Journal of Commerce \& Management, Vol. 13 No. 2, p. 29.

Jham, V. and Mohd, K. (2009), “Customer satisfaction and its impact on performance in banks: a proposed model", South Asian Journal of Management, Vol. 16 No. 2, pp. 109-26.

Kumar, M., Kee, F.T. and Charles, V. (2010), "Comparative evaluation of critical factors in delivering service quality of banks: an application of dominance analysis in modified SERVQUAL model", International Journal of Quality \& Reliability Management, Vol.27 No. 3, pp. 351-77.

Kumar, M., Kee, F.T. and Manshor, A.T. (2009), “Determining the relative importance of critical factors in delivering service quality of banks: an application of dominance analysis in SERVQUAL model", Managing Service Quality, Vol. 19 No. 2, pp. 211-28.

Ladhari, R. (2008), "Alternative measure of service quality: a review”, Journal of Managing Service Quality, Vol. 18 No. 1, pp. 65-86.

Lassar, W.M., Manolis, C. and Winsor, R.D. (2000), "Service quality perspectives and satisfaction in private banking", The Journal of Services Marketing, Vol. 14 No. 3, pp.244-71.

Lovelock, C. (2001), "Loyalty in private retail banking: an empirical study”, IUP Journal of Management Research, Vol. 9 No. 4, pp. 21-38.

Manrai, L.A. and Manrai, A.K. (2007), “A field study of customers' switching behaviour for bank services", Journal of Retailing and Consumer Services, Vol. 14, pp. 208-15.

Mishra, A.A. (2009), "A study on customer satisfaction in Indian retail banking”, IUP Journal of Management Research, Vol. 8 No. 11, pp. 45-61.

Naeem, H. and Saif, I. (2009), "Service quality and its impact on customer satisfaction: an empirical evidence from the Pakistani banking sector", The International Business and Economics Research Journal, Vol. 8 No. 12, p. 99.

Parasuraman, A., Berry, L.L. and Zeithaml, V.A. (1988), “SERVQUAL: a multiple-item scale for measuring consumer perceptions of service quality", Journal of Retailing, Vol. 64 No. 1, p. 12.

Prabhakaran, S. and Satya, S. (2003), “An insight into service attributes in banking sector", Journal of Services Research, Vol. 3 No. 1, pp. 157-69.

Sangwan, D.S. (2009), Human Resource Management in Banks, National Publishing House, New Delhi.

Stafford, M.R. (1996), “Demographic discriminators of service quality in the banking industry", The Journal of Services Marketing, Vol. 10 No. 4, p. 6.

Storbacka, K. (2000), "Customer profitability: analysis and design issues”, in Sheth, J. and Parvatiyar, A. (Eds), Handbook of Relationship Marketing, Sage, Thousand Oaks, CA.

Zeithaml, V.A. and Bitner, M.J. (1996), Services Marketing, International edition, McGrawHill,London. 